\title{
Cutaneous Melanoma cM1a(0) TNM Finding v8
}

National Cancer Institute

\section{Source}

National Cancer Institute. Cutaneous Melanoma cM1a(0) TNM Finding v8. NCI

Thesaurus. Code C136898.

Cutaneous melanoma with distant metastasis to skin, soft tissue including muscle, and/or nonregional lymph node. LDH level not elevated. (from AJCC 8th Ed.) 